\title{
Laboratory Diagnosis of Enteric Fever: A Review Update
}

\author{
Safia Sultana ${ }^{1}$, Md. Abdoullah Al Maruf ${ }^{2}$, Rabeka Sultana ${ }^{3}$, Shahanaz Jahan ${ }^{4}$
}

\begin{abstract}
${ }^{1}$ Assistant professor, Department of Microbiology, Shaheed Syed Nazrul Islam Medical College, Kishoreganj, Bangladesh; ${ }^{2}$ Residential Medical Officer, 250 Bed District Hospital, Kishoreganj, Bangladesh; ${ }^{3}$ Register (Gynaecology and Obstetrics), Shaheed Syed Nazrul Islam Medical College, Kishoreganj, Bangladesh; ${ }^{4}$ Assistant Professor of Pathology, Community Based Medical College, Mymensingh, Bangladesh
\end{abstract}

[Received: 1 July 2016; Revised: 12 October 2016; Accepted: 26 November 2016; Published: 1 December 2016]

\begin{tabular}{|c|}
\hline \\
\hline $\begin{array}{l}\text { The diagnosis of typhoid fever on clinical presentations alone is difficult, as the presenting symptoms are } \\
\text { diverse and similar to those observed with other febrile illnesses, especially during the first weeks of the } \\
\text { infection. Therefore, laboratory-based investigations are essential for supporting the diagnosis of the } \\
\text { disease. The "gold standard" for diagnosis of typhoid fever is the isolation of Salmonella typhi from } \\
\text { appropriate samples including blood, bone marrow aspirates, stool, urine and rose spots. This facility is } \\
\text { not available in many areas where the disease is endemic. Serodiagnosis depends upon the } 100 \text {-year-old } \\
\text { Widal test, and other serological diagnostic tools have limitations because of their low sensitivity and/or } \\
\text { specificity. The development of molecular methods for diagnosis of infectious diseases, including typhoid } \\
\text { fever has improved the sensitivity and specificity of diagnosis. One of the molecular methods, Polymerase } \\
\text { chain reaction (PCR) is the most sensitive and rapid method to detect microbial pathogens in clinical } \\
\text { specimens. Antigen detection has not been investigated for well over three decades and detecting an } \\
\text { immune response specific for typhoid fever has been done only with antibody detection. There is an } \\
\text { urgent need for the rational design and evaluation of effective and appropriate diagnostics for typhoid } \\
\text { fever which must include the emerging threat of } S \text {. typhi. However, monitoring of antibiotic susceptibility } \\
\text { patterns will ensure that signs of developing resistance are detected early and that the appropriate action is } \\
\text { taken. Therefore, this present review has been designed to describe the different diagnostic procedure of } \\
\text { typhoid fever. [Bangladesh Journal of Infectious Diseases } 2016 ; 3(2): 43-51]\end{array}$ \\
\hline Keywords: Enteric Fever; typhoid fever; Salmonella typhi \\
\hline $\begin{array}{l}\text { ence: Dr. Safia Sultana, Assistant Professor, Department of Microbiology, Shaheed Syed Nazrul Islam Medical } \\
\text { oreganj, Bangladesh; Cell no: }+8801712558404 \text {; Email: drsafia79@ yahoo.com } \\
\text { terest: There is no conflict of interest to any of the authors of this article. } \\
\text { ncy: This research work was performed by own cost. There was funding agency had given the support. } \\
\text { to authors: SS, MAAM, RS and SJ involved from the literature serached, preparation and revision of the } \\
\text { this article: Sultana S, Maruf MAA, Sultana R, Jahan S. Laboratory Diagnosis of Enteric Fever: A Review Update. } \\
\text { ournal of Infectious Diseases 2016;3(2):43-51 }\end{array}$ \\
\hline
\end{tabular}




\section{Introduction}

Laboratory diagnosis of typhoid fever is based on isolation and identification of Salmonella typhi from a suitable clinical specimen such as blood, stool, urine, bone marrow, and duodenal aspirate by culture, detection of $S$. typhi specific antibodies by serological test and antigen by immunological test and identification of nucleic acid by Polymerase chain reaction ${ }^{1}$.

\section{Isolation of the organism}

Culture isolation of the S. typhi remains the most effective diagnostic procedure in suspected typhoid fever. Where culture is available, typhoid fever may account for two thirds of cases of community acquired septicaemia admitted to hospital ${ }^{2}$. Blood has been the mainstay of culture for $S$. typhi since 1900. S. typhi maximally isolated from blood in the first week of disease; from faeces in the second and subsequent weeks and urine in the third and fourth weeks ${ }^{3}$. The various culture methods available are blood culture, clot cultures, faeces culture, bone marrow culture, urine culture, bile culture and duodenal aspirate culture.

\section{Blood Culture}

Blood culture is the gold standard diagnostic method for diagnosis of typhoid fever ${ }^{4}$. The sensitivity of blood culture is highest in the first week of the illness and reduces with advancing illnesses ${ }^{5}$. The organisms may be recovered from bloodstream at any stage of the illness, but are most commonly found during the first 7 to 10 days and during relapses ${ }^{6}$. Blood culture is the method of choice and has the great advantage over culture from the faeces, urine or bile. It is showing not only that patient is infected with the bacillus but that the infection is active ${ }^{7}$. Though it is gold standard, the yield of blood culture is quite variable. In the untreated patient, blood culture is usually positive in about $80.0 \%$ during first week and declining 20.0 to $30.0 \%$ later in the course of the disease ${ }^{8}$. Sensitivity of cultures can be affected by antibiotic treatment of the patient, inadequate sampling, type of culture medium, lengths of incubation, and variations of bacteraemia in the patients. In addition, Salmonella cultures take 4 to 7 days for isolation and identification of the organisms ${ }^{9}$. Adequate volumes of medium should be used in blood culture system to avoid negative results. A study finding suggested that $50 \mathrm{ml}$ of medium was adequate for $8 \mathrm{ml}$ of blood, presumably because of very low degrees of bacteraemia in some patients ${ }^{10}$.
If whole blood is to be cultured, it is essential to prevent bactericidal effects of serum either by adequate dilution of the sample in an adequate medium volume or by inhibition of serum bactericidal factors. Sodium polyanethol sulfonate (SPS) and bile salt inhibit this bactericidal effect ${ }^{7}$. The SPS in concentration of $0.025 \%$ to $0.03 \%$ is the best anticoagulant for blood. It is also anticomplementary and antiphagocytic, and interferes with the activity of some anti microbial agents, notably amino glycosides ${ }^{11}$. A study was reported that SPS aids in early recovery of $S$. typhi and S. Paratyphi A from blood cultures ${ }^{12}$. Taking samples of blood on several occasions may improve the results of culture ${ }^{13}$. Three types of blood cultures have been in use such as traditional or conventional blood culture, lysis centrifugation and automated blood culture ${ }^{14}$.

\section{Traditional or Conventional Technique}

Tryptone soya broth, bile broth or glucose broth, brain heart infusion broth are usually used for conventional methods of blood culture. The media is incubated aerobically at $37^{0} \mathrm{C}$. Subculture should be done on MacConkey's agar, blood agar media daily for 1 week and checked for turbidity, gas formation and other evidence of growth after 1,2, 3 and 7 days. For days 1, 2 and 3 only bottles showing signs of positive growth are cultured on agar plates. On day 7 all bottles should be subcultured before being discarded as negative ${ }^{10}$.

\section{Automated Technique}

Modern blood culture techniques (automated) permit the bacteriological confirmation of typhoid fever in a higher proportion of cases. These systems employ equipment that automatically detects an early sign of bacterial growth in a special blood culture bottle $^{14}$. An isolation rate of $92 \%$ of blood culture with the Bactec 460 Radiometric system using a blood: broth ratio of 1:6 was found in a study ${ }^{15}$.

\section{Lysis Centrifugation}

Lysis centrifugation system consists of a tube containing anticoagulant (SPS), EDTA, and saponin. After the tube is filled with blood during phlebotomy, the contents are mixed and centrifuged and the resulting pellet is inoculated onto agar media taking all aseptic measures. The system effectively recovers $S$. typhi from blood specimen ${ }^{16}$. The benefit of this system include; the more rapid and greater recovery of the organism; the presence 
of actual colonies for direct identification and susceptibility testing after initial incubation; the ability to quantify the colony forming units present in the blood; rapid detection of polymicrobial bacteraemia; and possible recovery of intracellular microorganisms caused by lysis of host cells. Limitation of the method is high rate of possible contamination $^{11}$.

\section{Clot Culture}

The blood clot culture was found to be much more sensitive for $S$. typhi than whole blood culture. Bacterial growth was significantly faster in cultures of blood clot compared to whole blood. The rapid confirmation of the aetiological agent would facilitate an early institution of appropriate antimicrobial therapy, thereby reducing clinical morbidity, especially in an endemic population ${ }^{17}$. Blood clot from which serum has been removed often gives a positive result when a similar volume of whole blood yields no growth ${ }^{7}$. A method of clot culture with streptokinase has been recommended ${ }^{18}$. An amount of $8 \mathrm{ml}$ quantities of venous blood is taken from patient and allowed to clot in sterile screw capped universal containers. The separated serum is removed. The medium used consists of a Wilson and Blair agar slope in a $120 \mathrm{ml}$ bottle to which is added $15 \mathrm{ml}$ of streptokinase bile salt broth. The streptokinase causes rapid clot lysis with release of bacteria trapped in the clot. The cultures are then incubated and positive results may be obtained in less than 24 hours $^{18}$. Clot culture is more sensitive than blood cultures with isolation rate of $92 \%$ and the clot technique has many advantages over conventional whole blood culture, both in reliability and in $\operatorname{cost}^{10}$.

\section{Culture of the Mononuclear Cell: Platelet Fraction of Blood}

The moderate or low sensitivity of blood culture is probably due to low concentration of S. typhi $(<10$ bacteria per $\mathrm{ml}$ ) in cells of the blood of patients with typhoid fever. Virtually all intracellular $S$. typhi are found within only mononuclear cells (MNC) and platelets. By the method of culture of mononuclear cells (MNC) and platelets fraction of blood from typhoid patients is subjected to density gradient centrifugation to isolate the mononuclear cells. Colonies of $S$. typhi were present in all mononuclear cell-platelet layer-positive cultures within 18 hours of plating and were identified within an additional 10 minutes by a coagglutination technique. In contrast, identification of all positive culture by conventional blood culture required 3 days ${ }^{19}$.

\section{Bone Marrow Culture}

Salmonella typhi is an intracellular pathogen in the reticuloendothelial cells of the body including the bone marrow. The overall sensitivity of bone marrow cultures ranges from 80.0 to $95.0 \%$ and is good even in the late phase of the disease and despite prior antibiotic therapy ${ }^{4}$. Bone marrow aspirates are known to yield a higher rate of positive cultures than peripheral blood in typhoid fever cases ${ }^{20-21}$. Bone marrow culture may give a positive result when blood culture fails, particularly in patients admitted to hospital while on antibiotic treatment. As a result unlike blood culture bone marrow culture is highly (90\%) sensitive ${ }^{22}$. Another study reported that the concentration of S. typhi in the bone marrow was found considerably higher than in peripheral blood ${ }^{23}$. In the bone marrow there were over 10 times more bacteria than in peripheral blood. it seems likely to the positively rate of a $1 \mathrm{ml}$ bone marrow culture is equivalent to the result of $10 \mathrm{ml}$ of peripheral blood ${ }^{23}$. The invasive nature of bone marrow aspiration discourage from its use as a first line investigation for diagnosis of typhoid fever ${ }^{24}$.

\section{Stool Culture}

In typhoid fever, stool cultures are usually positive from the second week of the infection. Stool is usually plated on desoxycholate- citrate agar and also inoculated into fluid enrichment media such as tetrathionate or selenite broth. The limitation of liquid of medium is that the growth of fluid enrichment medium is subcultured appropriate medium for proper identification. Suspicious colonies from culture plates are tested directly for the presence of salmonella $\mathrm{O}$ antigens by slide agglutination and subcultured to peptone water for determination of $\mathrm{H}$ antigen structure and for further biochemical analysis ${ }^{6}$.

\section{Urine Culture}

Urine cultures are not recommended for diagnosis in view of poor sensitivity ${ }^{4,21}$. Bacteria are not excreted continuously and therefore, several specimens may need to be cultured before organisms can be isolated ${ }^{25}$. In typhoid fever, urine cultures are usually positive from the third week of the infection. The centrifuged urine deposit is plated on desoxycholate-citrate agar and is also inoculated into fluid enrichment media such as tetrathionate or 
selenite broth. The growth of fluid enrichment medium is subcultured appropriate medium for proper identification ${ }^{6}$.

\section{Duodenal String: Capsule Culture}

Duodenal string test was found to be a simple, noninvasive and a reliable test which when used in combination with blood culture could identify almost all cases of typhoid fever irrespective of duration of fever and prior use of antibiotics ${ }^{26}$. Duodenal content cultures have been proved to be more sensitive $(86 \%)$ in diagnosis than bone marrow (75\%) and more effective than blood (42\%) and stool $(26 \%)$ cultures in recovery of $S$. typhi. The sensitivity of duodenal content cultures was found not modified by the duration of illness at admission or by previous antibacterial therapy ${ }^{27}$. Culture of duodenal aspirate is important in the detection of typhoid carriage. Individuals can excrete $S$. typhi in the bile and yet be undetected by stool culture ${ }^{28}$. Because of patient's discomfort and the time required for tube placement, duodenal aspiration has not been widely used ${ }^{29}$.

\section{Antibody Detection Tests (serology)}

\section{Widal test}

The information regarding Widal test has been noted in Britannica encyclopaedia. The Widal agglutination test was introduced as a serologic technique to aid in diagnosis of typhoid fever. The test was named after Georges Fernand Isidore Widal, a French physician and bacteriologist. In 1896, Widal developed a procedure for diagnosing typhoid fever based on the fact that antibodies in the blood of an infected individual cause the bacteria to bind together into clumps (the Widal reaction $)^{30}$. The test was based on demonstrating the presence of agglutinin (antibody) in the serum of an infected individual, against the $\mathrm{H}$ (flagellar) and $\mathrm{O}$ (somatic) antigens of Salmonella typhi ${ }^{8}$. The "O" antigen is the somatic antigen of $S$. typhi and is shared by $S$. paratyphi A, $S$. paratyphi B, other Salmonella species and other members of the Enterobacteriaceae family ${ }^{31}$. Antibodies against the $\mathrm{O}$ antigen are predominantly $\mathrm{IgM}$, rise early (appear on day 6 to 8 ) in the illness and disappear early ${ }^{31}$. The $\mathrm{H}$ antigens are flagellar antigens of $S$. typhi, paratyphi A and paratyphi B. Antibodies to $\mathrm{H}$ antigens are both IgM and IgG, rise late (on days 10 to 12) in the illness and persist for a longer time ${ }^{31-32}$. Serological diagnosis relies classically on the demonstration of a rising titre of antibodies in paired samples at an interval of 10 to 14 days $^{33}$. In typhoid fever, however, a four- fold rise after 2 weeks in not always demonstrable, even in blood culture confirmed cases. This situation may occur when the acute phase sample is obtained late in the natural history of the disease, because of high levels of probable background antibodies in an endemic region, or because in some individuals the antibody response is blunted by the early administration of an antibiotic $^{34}$. There is a controversy about the predictive value of $\mathrm{O}$ and $\mathrm{H}$ antibodies for diagnosis of enteric fever. Some authorities claim that $\mathrm{O}$ antibodies have superior specificity and positive predictive value (PPV) because these antibodies decline early after an acute infection ${ }^{34}$. It can be negative in up to $30.0 \%$ of culture- proven cases of typhoid fever. The purity and standardization of antigens used for the Widal test is a major problem and often results in poor specificity and poor reproducibility of test results ${ }^{32}$. The causes of a positive Widal agglutination test have been established; the patient being tested has typhoid fever; previous immunization with Salmonella antigen; cross-reaction with non-typhoidal Salmonella; infection with other enterobacteriaceae; other diseases such as dengue, schistosomal infection, chronic liver disease associated with raised globulin levels; and disorders such as rheumatic fever, rheumatoid arthritis, multiple myeloma, nephritic syndrome and ulcerative colitis $^{25}$. False negativity is one of the obstructive features of the Widal test. Hosoglu et $\mathrm{al}^{35}$ conducted a study to evaluate the associated factors with Widal test negativity in an endemic area. Widal test negativity was retrospectively analyzed by them among culture-proven typhoid fever cases. The potential features including age, gender, and previous antibiotic usage, duration of symptoms, leucopoenia, haematocrit value, and erythrocyte sedimentation rate (ESR) were evaluated for association with Widal test negativity ${ }^{35}$. It has been shown that the antibody response to the $\mathrm{O}$ antigen of $S$. typhi was markedly reduced in acute episodes of malaria compared to controls and that humoral immunity is transiently impaired ${ }^{36}$. In a study, subjects with dual infection of malaria and typhoid fever had significantly higher rates of nausea, vomiting, abdominal pain, and diarrhea the common features of enteric fever ${ }^{37}$. In the last two decades, this relationship between the two diseases has been reported in studies from Africa and India $^{38-40}$. A study conducted in Cameron found that the number of fever cases diagnosed as malariatyphoid fever co-infection were actually overestimated $^{38}$.

\section{Immunochromatographic method}


ICT has been studied in many countries and they found significantly higher sensitivity and specificity $^{41-43}$. An evaluation of ICT (Typhidot) in India was found to be $100 \%$ sensitive and $80 \%$ specific compared to a blood culture as gold standard $^{41}$.

\section{Haemagglutination (HA) Tests}

Many researchers have evaluated the usefulness of HA tests in different countries. In a study from India, the anti-LPS HA test showed a sensitivity of $60 \%$ and specificity of $98.2 \%$. The positive predictive value and negative predictive value were $66.7 \%$ and $96.7 \%$ respectively. In the same study, the haemagglutination inhibition test targeted Salmonella antigens and was found useful for helping the early detection of $S$. typhi in culture ${ }^{44}$. In another study, a Reverse Passive Haemagglutination Test (RPHA) was designed for the detection of $S$. typhi antigen. The test was found to be $70 \%$ sensitive and $92 \%$ specific for acute typhoid fever diagnosis ${ }^{45}$.

\section{Countercurrent Immunoelectophoresis (CIE)}

This test is based on electrophoresis and the visualization of the precipitin band of antigenantibody complexes that form. The sensitivity is similar to that of the Widal test and the procedure may be quicker if tests are batched (about one hour for a gel), but bands are often difficult to see, the cost is higher than that of the Widal, and some studies conclude that CIE has a low sensitivity with $\mathrm{Vi}$ antigen. A panel of antigens (somatic (O), flagellar $(\mathrm{H})$ and capsular polysaccharide (Vi) antigens of $S$. typhi is recommended for rapid diagnosis of typhoid fever ${ }^{46}$.

\section{Other serological test}

In view of the limitations of the Widal test and need for a cheap and rapid diagnostic method, several attempts to develop alternative serologic tests have been made. These include rapid dipstick assays, dot enzyme immuno-assays and agglutination inhibition tests.

\section{Antibody Detection}

\section{Dot Enzyme Immunoassay (EIA) Test}

A dot enzyme immunoassay that detects $\mathrm{IgG}$ and IgM antibodies against a $50 \mathrm{KD}$ outer membrane protein, distinct from the somatic $(\mathrm{O})$, flagellar $(\mathrm{H})$ or capsular (Vi) antigen of Salmonella typhi is commercially available as Typhidot ${ }^{47}$. Commercially it is available in two different properties like the Typhidot $M$ that detects only IgM antibodies of $S$. typhi has been reported to be slightly more specific in a couple of studies ${ }^{48-49}$. Typhidot ${ }^{\circledR}$ test detects specific IgM and IgG antibodies to $S$. typhi. It has undergone full-scale multinational clinical evaluation of its diagnostic value $^{50}$. In areas of high endemicity, where the rate of S. typhi transmission is high, the detection of specific IgG increases. The IgG can persist for more than two years after typhoid fever Infection ${ }^{51}$. The detection of specific IgG can not differentiate between acute and convalescent cases ${ }^{48}$.

\section{IgM Dipstick Test}

A rapid dipstick assay for the detection of S. typhispecific IgM antibodies in serum and whole blood samples was previously reported and the sensitivity and specificity was evaluated ${ }^{47,49}$. The dipstick assay may thus also be useful for the serodiagnosis of culture-negative patients with clinical signs and symptoms consistent with typhoid fever. The advantages of the dipstick assay are that the result can be obtained on the same day allowing a prompt treatment, that only a small volume of serum is needed, and that no special laboratory equipment is needed to perform the assay. The stability of the reagents of the dipstick and the simplicity of the assay allows its use in places that lack laboratory facilities ${ }^{49}$.

\section{Antigen Detection Tests}

There is clearly a demand for a simple diagnostic test for typhoid fever. An ideal test is reliable, simple, and affordable for the countries where the need is the greatest. Many of the affected countries are poor, and some places do not have electricity. The antigen detection, rather than antibody detection, could provide such a test ${ }^{52}$.

\section{Protein and Vi Antigens}

Enzyme immuno-assay, counter immune electrophoresis and co-agglutination tests to detect serum or urinary somatic/flagellar/Vi antigens of $S$. typhi have been evaluated ${ }^{45,53}$. Sensitivity of Vi antigen had been found to be superior than somatic and flagellar antigen, had been reported as ranging from 50 to $100 \%$ in different studies ${ }^{45,53}$. Similarly, specificity estimates have been reported to vary from $25.0 \%$ to $90.0 \%$. The suboptimal and variable sensitivity and specificity estimates, inability to detect $S$. paratyphi infection and $\mathrm{Vi}$ antigen 
negative strains of $S$. typhi are serious limitations of the $\mathrm{Vi}$ antigen detection tests. S. typhi antigen can be detected in the urine of some typhoid patients by co-agglutination test ${ }^{54}$. A monoclonal antibody specific for group D Salmonellae antigen 9 was used in an indirect enzyme-linked immunosorbent assay (ELISA) for detecting the antigen in urine specimens collected from patients with clinical typhoid fever in Jakarta, Indonesia. The ELISA had a sensitivity of $95.0 \%$ in identifying patients in whom $S$. typhi was isolated from blood cultures, $73.0 \%$ in patients in whom S. typhi was isolated from stool specimens, and $40.0 \%$ in patients in whom the organism was isolated from bone marrow cultures, but specificity varies from 25.0 to $90.0 \%{ }^{55}$.

\section{Molecular Methods}

The molecular method for diagnosis of typhoid fever has been evolved to overcome the limitations of cultures and serologic tests. Many authors have explored the use of polymerase chain reaction (PCR) for detecting specific DNA sequence of the organisms present in clinical specimens. The PCR as a diagnostic modality for typhoid fever was first evaluated in 1993 when Song et al successfully amplified the flagellin gene of S. typhi in all cases of culture proven typhoid fever and from none of the healthy controls. By using two pairs of primers evaluated in the study by Song et al, amplification of the flagellin gene of $S$. typhi confirmed the presence of the organism in the patient's blood ${ }^{56}$.

\section{PCR}

The PCR has been used to enable diagnosis of typhoid fever within few hours and more specific and sensitive than blood cultures.In addition nested PCR has been shown promising results. These results show that the nested PCR has good potential to be a rapid tool for the definitive, differential diagnosis of typhoid and is superior to conventional methods ${ }^{57}$.

\section{Nested PCR}

The nested PCR resulted in amplified fragments that were visible after agarose gel electrophoresis. The whole procedure to identify $S$. typhi DNA in the blood by agarose gel electrophoresis took only 16 hours, demonstrating the PCR to be a specific and rapid method for the early diagnosis of typhoid fever ${ }^{56}$. Frankel et $\mathrm{al}^{58}$ amplified flagellin gene sequences specifically from S. typhi. Massi ${ }^{59}$ in the year 2005 conducted a study to establish the nested PCR for DNA detection of $S$. typhi in the urine of patients with suspected typhoid fever. This research was used 107 urine samples from patients suspected with typhoid fever which were examined with nested PCR using two primer pairs with the final amplification result of 343 basepair (bp). This study reported that $64(59 \%)$ urine samples were positive with $S$. typhi DNA. This research concluded that nested PCR specifically from urine specimen can be used as an alternative method in diagnosis and management of typhoid fever ${ }^{59}$. Kumar et al ${ }^{60}$ used blood samples from 40 clinically suspected cases of typhoid fever, and found 20 of 20 culture positive and 12 of 20 culture negative cases to be positive by PCR in Delhi, India. Using single primer in South Sulawesi, Indonesia, 46 of $73(63.0 \%)$ blood samples collected from patients with clinically suspected typhoid fever were positive by PCR compared to $13.7 \%$ positive by blood culture ${ }^{59}$. In Varnassi, India, nested PCR was again better 53 of $57(73.0 \%)$ were positive than blood culture 17 of $53(32 \%)$ were positive on specimens from 63 clinical typhoid fever $\operatorname{cases}^{61}$. A large, welldesigned study in Indonesia investigated 131 patients with a clinical diagnosis of typhoid fever and diagnosed the cases by blood culture and PCR from blood $(84.5 \%)$ and urine samples $(69.3 \%)$. The PCR diagnosis was found more sensitive than the blood culture $(61.8 \%)^{62}$. A study from Nepal on specimens from 71 children with suspected typhoid fever reports $82.7 \%$ positivity for PCR from blood and urine, showing similar results for each specimen and PCR results were much higher than blood culture (26.9\%). In Pakistan, 55 cases of suspected typhoid fever and a control group of 20 healthy persons were diagnosed by PCR from blood samples and blood culture. The PCR and blood culture gave $58.2 \%$ and $14.5 \%$ positivity, respectively showing significantly better results by PCR ${ }^{63}$. Again in Pakistan, a multiplex PCR targeting five different genes for differential diagnosis of typhoidal pathogens has been developed for use directly on clinical blood samples. Of 42 multiplex PCR-positive blood samples, 35 were positive for $S$. typhi and two for $S$. Paratyphi $A$ and interestingly remaining 5 patients were found to have mixed infection ${ }^{57}$. Moreover, some patients with culture negative typhoid fever were PCR positive suggesting that PCR diagnosis of typhoid fever may have superior sensitivity than cultures. Over the next 10 years, a handful of studies have reported PCR methods targeting the flagellin gene, somatic gene, Vi antigen gene, 5S23S spacer region of the ribosomal RNA gene, invA gene and hilA gene of $S$. typhi for diagnosis of typhoid fever ${ }^{61,63-64}$. These studies have reported excellent sensitivity and specificity when compared to positive (blood culture proven) and healthy 
controls. The time required for diagnosis has been less than 24 hours $^{24}$. Chaudhry et $\mathrm{al}^{65}$ developed standardization of PCR for the detection of S. typhi in typhoid fever. The PCR technique was used for detection of $S$ typhi in blood or clot cultures from 84 patients clinically suspected of having typhoid fever, and from 20 healthy controls. Twenty five of 84 samples from clinically suspected cases were positive by PCR; four of which were culture negative. No amplification was seen in samples from patients who were culture positive for organisms other than S. typhi or from controls. The time taken for each sample for PCR analysis was less than 48 hours, compared with three to five days for blood or clot culture. The PCR was found to appear to be a promising diagnostic test for typhoid fever ${ }^{65}$.

\section{Multiplex PCR}

Multiplex PCR has been successfully applied for differential diagnosis of many diseases caused by viruses, bacteria, fungi, and parasites ${ }^{66-67}$. The multiplex PCR technique was evaluated by Ali et al directly on blood samples of 60 clinically suspected cases of typhoid fever. The PCR detected typhoidal species in 42 cases, only 17 of which were culture positive. The presence of Salmonella in these samples was confirmed with genus-specific primers $^{68}$. Quick multiplex PCR-based detection method was developed for early diagnosis of typhoid fever, using specific genetic markers of $S$. typhi. Primers of tyv gene, flag gene, viaB gene and ratA gene confirmed the specificity and sensitivity of the PCR. The serum samples of the suspected typhoid patients were taken directly for PCR without culturing the organism and extracting genomic DNA. Overall diagnosis required 2 hours which is the least time ever reported for a PCR based method. The sensitivity of the method was up to 5 famtogram (fg) genomic DNA. The genetic markers were specific and the four pairs of primers give selective amplification and differentiate $S$. typhi from closely related $S$. typhimurium ${ }^{69}$.

\section{Conclusion}

Several tests can be performed to diagnose typhoid fever. PCR is a new advance diagnostic test for typhoid fever and it is highly sensitive and specific for the early and reliable diagnosis of the disease than the blood culture, the widal and other serological tests. Although the PCR method requires extensive infrastructure and specialized skilled personnel, and cannot be made available everywhere, especially in developing countries, it can be made available to the reference centres for utilizations by other healthcare facilities following referral system. In fact, due to the rapid and definitive diagnosis, hospital admission of the patient can be avoided, reduce patients' suffering, save working days and unnecessary expenditure on unrelated and misdirected treatment which may be many times more than the cost of PCR.

\section{References}

1. Pearson RD, Guerrant RL. Enteric fever and other causes of abdominal symptoms with fever. In Principles Practices of Infectious Diseases (eds). Mandell GL, Bennet JE, Dolin R Churchill Livingstone, New York, London 1995; 998-1012

2. Hoa NT, Diep TS, Wain J, Parry CM, Hien TT, Smith MD, Walsh AL, White NJ.Community-acquired septicaemia in southern Viet Nam: the importance of multidrug-resistant Salmonella typhi, Trans R Soc Trop Med Hyg. 1998 Sep-Oct; 92(5):503-508

3. Old DC. Salmonella infection, In :Mackie and McCartney, Practical Medical Microbiology, $14^{\text {th }}$ edition, Collee, JG, Fraser, AG, Marmion, BP, Simons, A editors, Churchil Livingston, New York, 2006; 385-402

4. Parry CM, Hien. TT, Dougan G, White NJ, Farrar JJ. Typhoid fever, New England Journal of Medicine 2002;347(22): 1770-82

5. Ananthanarayan R and Panikar CKJ. In: Textbook of Microbiology, Chennai, Orient Longman 1999; 244-249

6. Lewis MJ. Salmonella, In: Medical Microbiology, Greenwood, D, Slack, R and Pebtherer, J, editors, $15^{\text {th }}$ edition, ELST, USA, 1997; 252-261

7. Parker MT. enteric infections: typhoid and paratyphoid fever, In: Topley and Wilson's Microbiology and Microbial infections, $8^{\text {th }}$ edition. Collies L. Balows A. Susman M. Arnold editors, London, 1990; 3: 423-446

8. Jenkins C, Gillespie SH. Salmonella Infections. In: Gordon C. Cook Zumla AI. eds. Manson's Tropical Diseases, 22nd edition. China: Saunders Elsevier 2009: 931-952

9. Miller IS and Pegues DA. Salmonella species, including Salmonella typhi, In: Mandell, Douglar and Bennetts principles and practice of infectious disease, Mandell, GL, Bennett, JE, Dolin, R, editors, $5^{\text {th }}$ edition, Philadelphia, Churchill Livingstone, 2000:2344-2263

10. Watson KC. Laboratory and Clinical Investigation of Recovery of Salmonella typhi from Blood, Journal of Clinical Microbiology, 1978;7(2):122-126

11. Betly A, Daniel FF, Alice SS. Weissfeld editors, Blood stream infection In: Baily and Scott's Diagnostics Microbiology, Mostby, Missouri, USA, $12^{\text {th }}$ edition, 2010: 865-880

12. Escamilla J, Santiago LT, Uylangco CV and Cross JH. Evaluation of Sodium Polyanethol Sulfonate as a Blood Culture Additive of Salmonella typhi and Salmonella paratyphi A, Journal of clinical Microbiology 1985; 18: 380-383

13. Le TP and Hoffman SL. Typhoid fever In: Tropical Infectious Diseases, Principles, Pathogena and practice, Guerrent, RL, Walker, DH, weller, PF editors, Churchill Livingstone, Philadelphia 1999; 1: 277-290

14. Collee JG and Marr W. Culture of bacteria In: Mackie and Cartney, Practical Medical Microbiology, Collee JG, Fraser, AG, Marmion, BP and Simmons, A editors, $14^{\text {th }}$ edition, Curchill Livingstone, India, 2006: 121-124 
15. Duthie R and French G. Comparison of methods for the diagnosis of typhoid fever. Journal of Clinical Pathology 1990; 43: 863-865

16. Rechard and Thompson. Specimen collection, transport and processing In: Murray PP, Baron EJ, Jorgensen JH, Landry ML, Pfaller MA. eds Manual of Clinical Microbiology $9^{\text {th }}$ edition Washington, DC. 2007; $1: 310$

17. Mantur BG, Bidari LH, Akki AS, Mulimani MS, Tikare NV. Diagnostic yield of blood clot culture in the accurate diagnosis of enteric fever and human brucellosis, Clin Lab. 2007; 53(1-2):57-61

18. Watson KC. A Method for the Isolation of Salmonella Typhi from Blood Clot, American Journal of Tropical Medicine and Hygiene 1956; 5: 131-132

19. Rubin F, McWhirter P. Rapid diagnosis of typhoid fever through identification of Salmonella typhi within 18 hours of specimen acquisition by culture of the mononuclear cell-platelet fraction of blood. J Clin Microbiol 1990; 28:825-827

20. Farooqui BJ, Khurshid M, Ashfaq MK, Khan MA. Comparative yield of Salmonella typhi from blood and bone marrow cultures in patients with fever of unknown origin. J Clin Pathol 1991;44:258-259

21. Gilman RH, Terminel M, Levine MM, HernandezMendoza P, Hornick RB. Relative efficacy of blood, urine, rectal swab, bone-marrow and rose-spot cultures for recovery of Salmonella typhi in typhoid fever. Lancet 1975;9: 1211-1213

22. Lesser CF and Miller SI. Salmonellosis, in Harrison's principle of internal Medicine, $16^{\text {th }}$ edition, Kasper, DL, Fauel, AS, Longo, DL, Braunwald, E, Hauser, SL, Jameson, J editors, McGraw- Hill Medical publishing Division, New York, 2005; 1:897-902

23. Wain J, Pham VB, Ha V, Nguyen NM, To SD, Walsh AL. Parry CM. Hasserjian RP. HoHo VA. Tran TH. Farrar J. White NJ. Day NP.Quantitation of bacteria in bone marrow from patients with typhoid fever: relationship between counts and clinical features J Clin Microbiol 2001;39(4):1571-76

24. Kundu R, Ganguly N, Ghosh TK, Yewale VN, Shah RC, Shah NK. IAP Task Force Report: Diagnosis of Enteric Fever in Children Indian Pediatr. 2006; 43(10):875-83

25. Chessbrough M. District laboratory practice in tropical countries, Part-2, New York, USA, Cambridge University, 2010; 184- 186

26. Antony TJ, Patwari AK, Anand VK, Pillai PK, Aneja S, Sharma D. Duodenal string test in typhoid fever. Indian Pediatr 1993 May; 30(5):643-7

27. Benavente L, Gotuzzo E, Guerra J, Grados O, Guerra H, Bravo N, Diagnosis of typhoid fever using a string capsule device, Transaction of the Royal Society of Tropical Medicine and Hygiene, 1984; 78(3): 404-406

28. Madanagopalan N, Subramaniam S, Panchanadaer M, Rao $\mathrm{P}$ and Suniti S. Detection of enteric carriers by upper small intestinal aspirate studies. Journal of Tropical Medicine and Hygiene, 1975; 78:123-125

29. Gilman RH and Richard BH. Duodenal Isolation of Salmonella typhi by String Capsule in Acute Typhoid Fever, Journal of Clinical Microbiology 1976; 3(4):456457

30. Encyclopedia Britannica. Fernand-Isidore Widal, Online, Web. 25 Apr. 2011; Updated on: 25 January 2008; Web Address:

http://www.britannica.com/EBchecked/topic/643157/Fern and-Isidore-Widal; Accessed: 28 April 2008

31. Rodrigues C. The Widal test more than 100 years old: abused but still used. Indian Journal Association of Physicians 2003; 51:7-8
32. Olopoenia LA and King AL. Widal agglutination test-100 years later: Still plagued by controversy. Postgraduate Journal of medicin 2000;76:80-84

33. Parry CM, Hoa NTT, Diep TS. Chinh JNT, Vinh H. Value of a single tube widal test in a diagnosis of typhoid fever in Vietnam. J Clin Microbiol 1999;37(9):2882-2886

34. Schoeder SA. Interpretation of serologic tests for typhoid fever, JAMA 1968; 206(4): 839-840

35. Hosoglu S, Bosnak V, Akalin S, Geyik MF, Ayaz C. Evaluation of false negativity of the Widal test among culture proven typhoid fever cases, J Infect Dev Ctries 2008;2(6):475-478

36. Greenwood BM, Bradley-Moore AM, Bryceson AD, Palit A. Immunosuppression in children with malaria. Lancet 1972; 4:169-172

37. Khan MA, Mekan SF, Abbas Z, Smego RA. Concurrent malaria and enteric fever in Pakistan, Singapore Med J 2005;46(11):635-8

38. Ammah A, Akenji NT, Ndip R and Deas JE. An update on concurrent malaria and typhoid fever in Cameroon, Transactions of the Royal Society of Tropical Medicine and Hygiene 1999;93(2):127-129

39. Ohanu ME, Mbah AU,Okonkwo PO, Nwagbo FS. Interference by malaria in the diagnosis of typhoid using Widal test alone, West Afr J Med 2003;22(3):250-252

40. Kanjilal SD, Dutta A, Mondal RK, Chakravorti S.Uncomplicated falciparum malaria complicated by Salmonella septicaemia: cause not coincidence, J Indian Med Assoc 2006;104(11):646, 648

41. Jesudason M, Esther E, Mathai E.Typhidot test to detect $\mathrm{IgG} \& \mathrm{IgM}$ antibodies in typhoid fever, Indian Journal of Medical Research 2002; 116: 70-72

42. Anusha R, Ganesh R, Lalitha J. Comparison of a rapid commercial test, Enterocheck WB, with automated blood culture for diagnosis of typhoid fever. Annals of Tropical Paediatrics: International Child Health 2011; 31(3): 231234

43. Pastoor R, Hatta M, Abdoel TH, Smits HL. A simple, rapid, and affordable point-of-care test for the serodiagnosis of typhoid fever. Diagn Microbiol Infect Dis 2008;61 (2): 129-134

44. Shukla S, Patel B, Chitinnis DS. 100 years of widal test and its reapparisial in an endemic area. Indian $\mathrm{J}$ Med Res. 1997 Feb; 105:53-57

45. Kalhan, R, Kaur, I, Singh, RP and Gupta, HC.Latex Agglutination Test (LAT) for the diagnosis of typhoid fever, Indian Pediatrics 1999; 36: 65-68

46. Sharma KB, Bhat BM, Paricha A, Vaze S. Multiple antibiotic resistance among Salmonellae in India, Journal of Antimicrobial and Chemotherapy 1979; 5:15-21

47. Gasem MH, Smits HL, Goris MG and Dolmans, WM. Evaluation of a simple and rapid dipstick assay for the diagnosis of typhoid fever in Indonesia, $\mathrm{J}$ Med Microbiol. 2002;51(2):173-177

48. Choo KE, Davis TM, Ismail A, Ibrahim TTA, Ghazali WN. Rapid and reliable serological diagnosis of enteric fever: comparative sensitivity and specificity of Typhidot and Typhidot-M tests in febrile Malaysian children, Acta Trop 1999; 72(2):175-83

49. Hatta M, Goris MG, Heerkens E, Gooskens J, Smits HL. Simple dipstick assay for the detection of Salmonella typhi-specific IgM antibodies and the evolution of the immune response in patients with typhoid fever. Am $\mathbf{J}$ Trop Med Hyg 2002 Apr; 66(4):416-21

50. Ismail AB, Kader ZSA, Ong KH. Dot enzyme Immunosorbent assay for the sero-diagnosis of typhoid fever. Southeast Asian J Trop Med Public Health 1991;22:563-66 
51. Bhutta ZA, Ali NM. Rapid serologic diagnosis of Pediatric typhoid fever in an endemic area: A prospective comparative evaluation of two DOT-EIA and the Widal test. Am J Trop Med Hyg 1999;61(4):654-57

52. Wain $\mathrm{J}$ and Hosoglu $\mathrm{S}$. the laboratory diagnosis of enteric fever, Journal of Infectious Developing Countries 2008;2(6):421-25

53. Fadeel MA, Crump JA, Mahoney FJ, Nakhla IA, Mansour AM, Reyad B. Rapid diagnosis of typhoid fever by enzyme-linked immunosorbent assay detection of Salmonella serotype typhi antigens in urine, Am J Trop Med Hyg. 2004;70(3):323-328

54. West B, Richens JE, Howard PF. Evaluation in Papua New Guinea of a urine coagglutination test and a Widal slide agglutination test for rapid diagnosis of typhoid fever, Trans R Soc Trop Med Hyg 1989;83(5):715-717

55. Chaicumpa W, Ruangkunaporn Y, Burr D, Nguan CM, Echeverria P. Diagnosis of typhoid fever by detection of Salmonella typhi antigen in urine, J Clin Microbiol. 1992;30(9):2513-2515

56. Song JA, Cho H, Park MY, et al. Detection of Salmonella typhi in the blood of patients with typhoid fever by polymerase chain reaction. J Clin Microbiol 1993; (3) 31: 1439-43

57. Ali A, Haque A, Sarwar Y. Multiplex PCR for differential diagnosis of emerging typhoidal pathogens directly from blood samples. Epidemiol Infect 2009;137:102-107

58. Frankel G, Newton SMC, Schoolnik GK, Stocker BAD. Unique sequences in region VI of the flagellin gene of Salmonella typhi, Mol Microbiol. 1989;3(10):1379-83

59. Massi MN, Shirakawa T, Gotoh A, et al. Rapid diagnosis of typhoid fever by PCR assays using one pair of primers from flagellin gene of S. typhi. J Infect Chemother 2003;9:233-237

60. Kumar A, Arora V, Bashamboo A, et al. Detections of Salmonella typhi by polymerase chain reaction: implification in diagnosis of typhoid fever, Infect Genet Evol 2002;2:107-110
61. Prakash P, Mishra OP, Singh AK, et al. Evaluation of Nested PCR in diagnosis of typhoid fever J Clin Microbiol 2005; 431-432

62. Hatta M and Smits HL. Detection of Salmonella typhi by nested polymerase chain reaction in blood, urine, and stool samples, American Journal of Tropical Medicine and Hygiene 2007; 76:139-143

63. Haque A, Ahmed N, Peerzada A, Utility of PCR in diagnosis of problematic cases of typhoid. Jpn J Infect Dis 2001; 54: 237-9

64. Sanchez-Jimenez MM, Cardona-Castro N, Validation of a PCR for diagnosis of typhoid fever and Salmonellosis by amplification of the hilA gene in clinical samples from Colombian patients. J Med Microbiol 2004; 53:875-78

65. Chaudhry R, Laxmi BV, Nisar N, Ray K, Kumar D. Standardisation of polymerase chain reaction for the detection of Salmonella typhi in typhoid fever, J Clin Pathol 1997;50(5): 437-439

66. Rithidech KN, Dunn JJ, Gordon CR. Combining multiplex and touchdown PCR to screen murine microsatellite polymorphisms, Bio Techniques 1997;23:36-45

67. Hirose K, Itoh K, Nakajima H, Kurazono T, Yamaguchi M, Moriya K. Selective amplification of prt ( $\mathrm{rfbS})$, viaB tyv (rfbE), and fliC genes by multiplex PCR for identification of Salmonella enterica serovars typhi and Paratyphi A. J Clin Microbiol. 2002; 40(2): 633-636

68. Kidgell C, Reichard U, Wain J, Linz B, Torpdahl M, Dougan G. Salmonella typhi, the causative agent of typhoid fever, is approximately 50,000 years old. Infect Genet Evol 2002;2(1):39-45

69. Kumar A, Balachandran Y, Gupta S, Khare S, Suman. Quick PCR based diagnosis of typhoid fever using specific genetic markers, Biotechnol Lett 2010;32(5):70712 